Indexed by

\title{
Scopus
}

\section{INCREASED PRODUCTIVITY OF LIQUID SMOKE THROUGH FAST THAWING WITH REFRIGERATION SYSTEMS AT LOW AIR TEMPERATURES}

Crossref

\author{
Baiti Hidayati \\ University of Sriwijaya, \\ Faculty of Engineering, \\ South Sumatera, \\ Indonesia
}

Muhammad Faizal

University of Sriwijaya, Faculty of Engineering, Chemical Engineering Department, South Sumatera, Indonesia

\author{
Riman Sipahutar \\ University of Sriwijaya, \\ Faculty of Engineering, \\ Mechanical Engineering \\ Department, South Sumatera, \\ Indonesia
}

KOBSON

I8 Google

\author{
Irwin Bizzy \\ University of Sriwijaya, \\ Faculty of Engineering, \\ Mechanical Engineering \\ Department, South Sumatera, \\ Indonesia
}

Key words: condensation, liquid smoke, low air temperature, palm shell, refrigeration doi:10.5937/jaes0-30849

Cite article:

Hidayati B., Sipahutar R., Bizzy I., Faizal M. (2022) INVESTIGATION OF THE METHOD OF PROCESSING HOLES WITH A ROTARY CUP CUTTER WITH SURFACING, Journal of Applied Engineering Science, 20(1), 79 - 84, DOI:10.5937/ jaes0-30849 


\title{
INCREASED PRODUCTIVITY OF LIQUID SMOKE THROUGH FAST THAWING WITH REFRIGERATION SYSTEMS AT LOW AIR TEMPERATURES
}

\author{
Baiti Hidayati', Riman Sipahutar ${ }^{2 *}$, Irwin Bizzy², Muhammad Faizal ${ }^{3}$ \\ ${ }^{1}$ University of Sriwijaya, Faculty of Engineering, South Sumatera, Indonesia \\ ${ }^{2}$ University of Sriwijaya, Faculty of Engineering, Mechanical Engineering Department, South Sumatera, \\ Indonesia \\ ${ }^{3}$ University of Sriwijaya, Faculty of Engineering, Chemical Engineering Department, South Sumatera, \\ Indonesia
}

Liquid smoke increased in demand by the community because it is made from environmentally friendly waste can directly reduce environmental pollution. The smoke condensing process that is carried out conventionally using water can be continuously replaced using a refrigeration system, the smoke condensation process can be carried out using controlled low-temperature air, this can minimize machine space and energy. In this study, an analysis of variations in air temperature will be carried out to maximize the productivity of liquid smoke. The raw material for palm kernel shell is $-4+5$ mesh with cabin temperature variations of $10-15^{\circ} \mathrm{C}, 5-10^{\circ} \mathrm{C}$, and $0-5^{\circ} \mathrm{C}$ and pyrolysis temperature of $300-400^{\circ} \mathrm{C}$. Based on the research results obtained maximum results at a temperature of $0-5^{\circ} \mathrm{C}$ with $23.6 \%$ liquid smoke, $3.7 \%$ tar, $63.8 \%$ charcoal, and $8.9 \%$ gas. The test results of chemical compounds, liquid smoke has an average phenol value of $56.59 \%$. The lower the air temperature used to condense the smoke, the maximum liquid smoke will be and the less gas escapes to the air. It can directly reduce air pollution in the process of making liquid smoke

Key words: condensation, liquid smoke, low air temperature, palm shell, refrigeration

\section{INTRODUCTION}

Indonesia is one of the countries that has a comprehensive area coverage, most of Indonesia's territory is used to achieve the welfare of the community, one of which is oil palm plantations that produce Crude Palm Oil (CPO) with $43 \%$ waste output [1]. Oil palm plantations in the Indonesia's territory in 2013 reached 10.6 million ha, in 2020 it increased to 13.7 million ha [2]. In one year, oil palm produces 6,000 tons of palm shell from 100,000 tons of fresh fruit bunches (FFB), 12 thousand tons of fibers, and 23 tons of empty fruit bunches. The amount of waste must be managed into a valuable and economical product such as liquid smoke [3]. Many ways have been taken in the management of palm shell waste such as environmentally friendly liquid smoke with various techniques and different results, as has been done by several researchers [4]-[6].

Palm kernel shell is one of the many types of solid waste from the palm oil processing industry which still causes problems for the environment, this waste is difficult to degrade in large quantities and is difficult naturally in the environment [7]. Palm kernel shells have varying amounts of lignin, hemicellulose, and cellulose depending on their content, palm kernel shells contain lignin $29.4 \%$, hemicellulose $27.7 \%$, and cellulose $26.6 \%$ [3].

Liquid smoke result from smoke condensation of the pyrolyzing process of raw materials contains lignin, cellulose, hemicellulose, and other carbon compounds [8], [9]. Liquid smoke has many benefits, including as a la- tex clotting liquid, preservative, biopesticide, neutralizing soil acid, improving soil quality, killing pests, insect repellents, and accelerating roots, stems, tubers, fruit, flowers, and leaves [10]. Research related to liquid smoke with palm kernel shells has been carried out as has been done by [11]-[20] and others.

Pyrolysis is decomposing organic compounds through a heating process either with little or no oxygen [21]. Pyrolysis can also be an organic thermal decomposition that can cause the formation of volatile compounds. The pyrolysis process generally ranges from $200^{\circ} \mathrm{C}$ to $500^{\circ} \mathrm{C}$ [22]. Biomass gasification is a good biomass processing process for energy production using conventional and renewable fuels. Gasification will produce hydrogen, carbon oxides, methane. The resulting gas contains complex inorganic and organic compounds such as tar [23].

In general, condensation is a process of changing the fluid phase from gas to liquid, because in the condensation process heat releases into the environment. Volatile organic compounds are the main source of air pollution, while the condensation process is a good way to overcome it [24]. The condensing process using a refrigeration system to form entropy has been carried out by [25]. In the liquid smoke production process, condensing is carried out using conventional water as is done [14], [19], [20], [22], [26]-[28]. The condensing process of smoke into liquid smoke is carried out conventionally using water circulated continuously using a pump. During 
the process of making liquid smoke, of course, there is still gas that escapes to the environment, this is because the water temperature continues to increase as a result of the condensing process [27].

Refrigeration is the process of transferring heat from one place to another from a low temperature to a higher temperature, in this process heat absorption and release occur [29]. In general, refrigeration systems are predominantly used for commercial equipment such as freezing and food conservation as the most related energy consumption [30].

In this study, a discussion of the liquid smoke condensing process will be carried out, the liquid smoke condensing process has been carried out conventionally using water distributed using a pump which will be replaced using low-temperature air using a refrigeration system. The smoke will be condensed using air cooled by the evaporator. The temperature control will also be varied, namely the temperature of $10-15^{\circ} \mathrm{C}, 5-10^{\circ} \mathrm{C}$, and $0-5^{\circ} \mathrm{C}$. From this variation in low air temperature, an analysis of the percentage of liquid smoke and gas that escapes to the environment will be carried out. So it is hoped that this research can reduce the gas that escapes due to the not condensed smoke.

\section{Materials and method}

The raw material used in making liquid smoke is palm shell waste with a size of $-4+5$ mesh. The raw material in the form of palm kernel shells is subjected to a laboratory test with the results listed in Table 1.

Table 1: Palm shell compounds

\begin{tabular}{|c|c|}
\hline Compound & Percentage (\%) \\
\hline Hemicellulose & 2.68 \\
\hline Cellulose & 11.52 \\
\hline Water content & 12.18 \\
\hline Lignin & 76.22 \\
\hline Ash & 3.19 \\
\hline
\end{tabular}

Table 1 shows the laboratory test results for the oil palm shell content, the moisture content looks very low $12.18 \%$, this is because the oil palm shells are dried using the sun. Meanwhile, the lignin value of the palm shell was high, reaching $72.22 \%$.

Palm shells with a weight of $10000 \mathrm{~g}$ are burned through a pyrolysis process with temperatures reaching $300^{\circ} \mathrm{C}-400^{\circ} \mathrm{C}$. From the results of the pyrolysis process, it will produce smoke which will then be directed to a cold storage room with various controlled temperatures, air with temperatures of $10^{\circ} \mathrm{C}-15^{\circ} \mathrm{C}, 5^{\circ}-10^{\circ} \mathrm{C}$, and $0^{\circ}-5^{\circ} \mathrm{C}$. The cold air in cold storage comes from the evaporator pipe which is a series of refrigeration systems. So that the air inside the cold storage can be controlled and can directly save energy. Air distribution in the cold storage will be moved using a fan. This production process is carried out continuously for 6 hours from each temperature variation, the cooling capacity can be seen in Table 2 .
Table 2: Cooling engine capacity

\begin{tabular}{|c|c|}
\hline Compressor & $1 \mathrm{HP}$ \\
\hline Refrigerant & R-22 \\
\hline Cooling Load & $9000 \mathrm{Btu} / \mathrm{hr}$. \\
\hline Fan Room & $5.4 \mathrm{~m} / \mathrm{s}$ \\
\hline
\end{tabular}

The smoke condensed due to the distribution of desired air originating from the refrigeration system will be divided into four categories, liquid smoke, charcoal, tar, and non-condensed gases.

The diagram of the liquid smoke production process using the refrigeration system is illustrated in Figure 1, and the piping diagram of the process of making liquid smoke using the refrigeration system is shown in Figure 2.

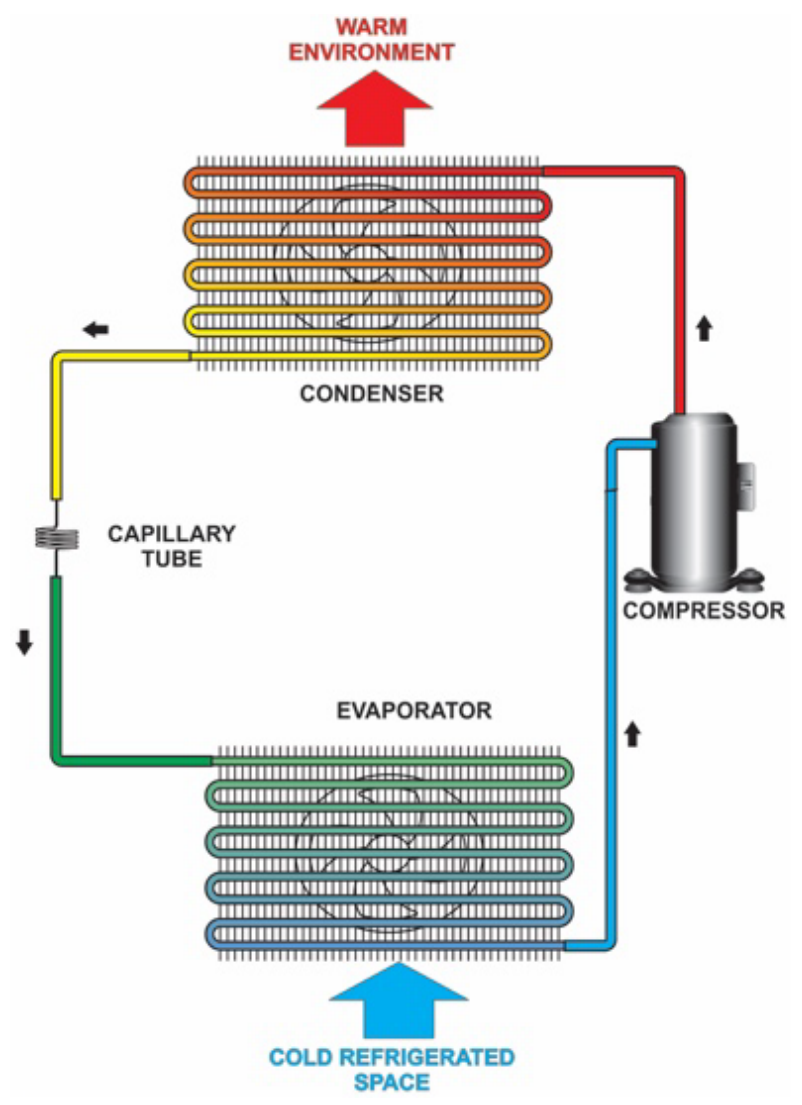

Figure 1: Vapor compression refrigeration cycle

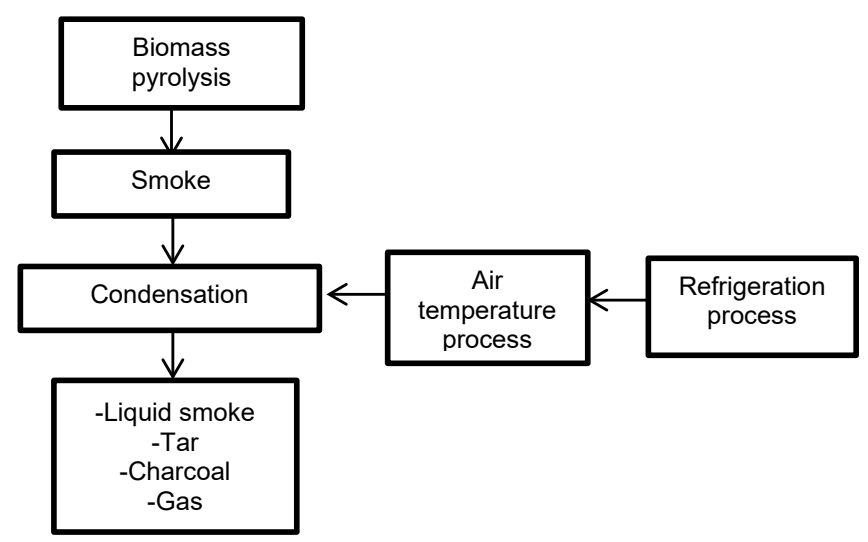

Figure 2: Diagram of the liquid smoke production process using a refrigeration system

Istraživanja i projektovanja za privredu ISSN 1451-4117 Journal of Applied Engineering Science Vol. 20, No. 1, 2022 
Figure 1 is the refrigeration cycle, in the refrigeration cycle consists of 4 main components, namely compressor, condenser, capillary tube, and evaporator. Also, there are various kinds of safety and control devices to save energy and keep the main components safer [31]-[35].

Figure 2 is a flow chart in the process of producing liquid smoke using a refrigeration system. The smoke from pyrolysis will be condensed using low-temperature air that comes from the evaporator of the refrigeration system and the air distribution is carried out by the fan.

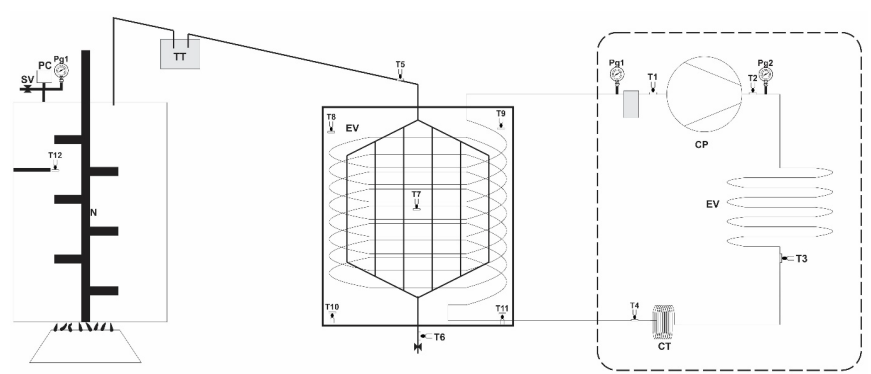

Figure 3: Piping diagram of the process of making liquid smoke with low air temperatures using a refrigeration system: (a) Reactor, (b) Cooling Room, (c) Refrigeration System

Can be seen in Figure 3 above, is a cycle of the process of making liquid smoke using a refrigeration system. The raw material for the palm kernel shells will be carried out by the pyrolysis process using a reactor tube where the main fuel is gas. The pyrolysis smoke will flow into the cooling room, the liquid smoke will be cooled by low-temperature air which is the result of evaporator cooling in the refrigeration system with air temperature control of $10-15^{\circ} \mathrm{C}, 5-10^{\circ} \mathrm{C}$, and respectively $0-5^{\circ} \mathrm{C}$. The result of this temperature variation will produce different charcoal, tar, liquid smoke, and gas.

\section{ANALYSIS}

The liquid smoke that goes through the refrigeration system process will be the percentage of liquid smoke, tar, charcoal, and gas will be calculated

$$
\begin{aligned}
& m_{s}=m_{l}+m_{t}+m_{c}+m_{g}=100 \% \\
& m_{l}(\%)=\frac{m_{l}(g r)}{m_{s}(g r)} \times 100 \% \\
& m_{t}(\%)=\frac{m_{t}(g r)}{m_{s}(g r)} \times 100 \% \\
& m_{c}(\%)=\frac{m_{c}(g r)}{m_{s}(g r)} \times 100 \% \\
& m_{g}(\%)=\frac{m_{g}(g r)}{m_{s}(g r)} \times 100 \%
\end{aligned}
$$

The equation above shows the percentage of calculation of palm oil, liquid smoke, tar, charcoal, and gas. $\mathrm{m}_{\mathrm{s}}$ is a percentage for the number of palm shells used, $m_{1}$ is the percentage amount for liquid smoke obtained, $m_{t}$ is the percentage of tar produced from the processpirolisis, $m_{c}$ is the percentage amount of charcoal left over from the pyrolysis process, and $\mathrm{m}_{\mathrm{g}}$ is the percentage amount of unconspired gas or gas that cannot turn into liquid smoke so that it passes into the environment and causes pollution.

\section{RESULTS AND DISCUSSION}

Making liquid smoke using a refrigeration system has its advantages, namely being able to speed up the process of making liquid smoke, save the capacity of the cooling room, use air as a condensing smoke distribution, use a compressor as the main heart of the cooling system, and can control air temperature. Thus able to save energy. Based on the research results, the results shown in Ta-

\begin{tabular}{|c|c|c|c|c|c|c|}
\hline \multirow{2}{*}{$\begin{array}{c}\text { Product of } \\
\text { pyrolysis } \\
\text { process }\end{array}$} & \multicolumn{2}{|c|}{$10-15\left({ }^{\circ} \mathrm{C}\right)$} & \multicolumn{2}{|c|}{$5-10\left({ }^{\circ} \mathrm{C}\right)$} & \multicolumn{2}{|c|}{$0-5\left({ }^{\circ} \mathrm{C}\right)$} \\
\hline & g & $\%$ & g & $\%$ & g & $\%$ \\
\hline $\begin{array}{c}\text { liquid } \\
\text { smoke }\end{array}$ & 1774.2 & 17.7 & 1805.8 & 18.1 & 2357.9 & 23.6 \\
\hline tar & 360.0 & 3.6 & 360.0 & 3.6 & 368.0 & 3.7 \\
\hline charcoal & 6400.0 & 64.0 & 6400.0 & 64.0 & 6380.0 & 63.8 \\
\hline gas & 1465.8 & 14.7 & 1434.2 & 14.3 & 894.1 & \begin{tabular}{|l|}
8.9 \\
\end{tabular} \\
\hline
\end{tabular}
ble 3 are obtained.

Table 3: The results of the mass loyalty low air temperature variations in increasing the productivity of liquid smoke using the refrigeration system

Based on the research result on making liquid smoke using a refrigeration system, maximum results were obtained at a controlled temperature of $0-5\left({ }^{\circ} \mathrm{C}\right)$ air with $23.6 \%$ liquid smoke and $8.9 \%$ minimum gas.

Figure 4 shows the percentage of the process of making liquid smoke using a refrigeration system, maximum results were obtained at a controlled temperature of $0-5^{\circ} \mathrm{C}$ air with $23.6 \%$ liquid smoke and $8.9 \%$ minimum gas. The results of the research on the condensation process using low-temperature air showed that the lower the temperature of the condensing process, the less the amount of gas that escaped to the environment.

Based on Figure 5, the results of liquid smoke increase by 165 minutes, the longer the liquid smoke results are reduced because the compounds in the palm shell are

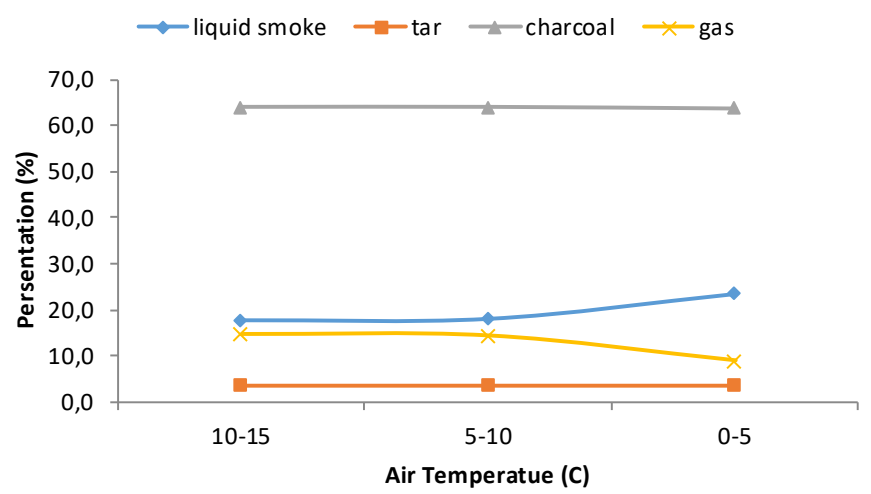

Figure 4: Liquid smoke production achievement with temperature variations 


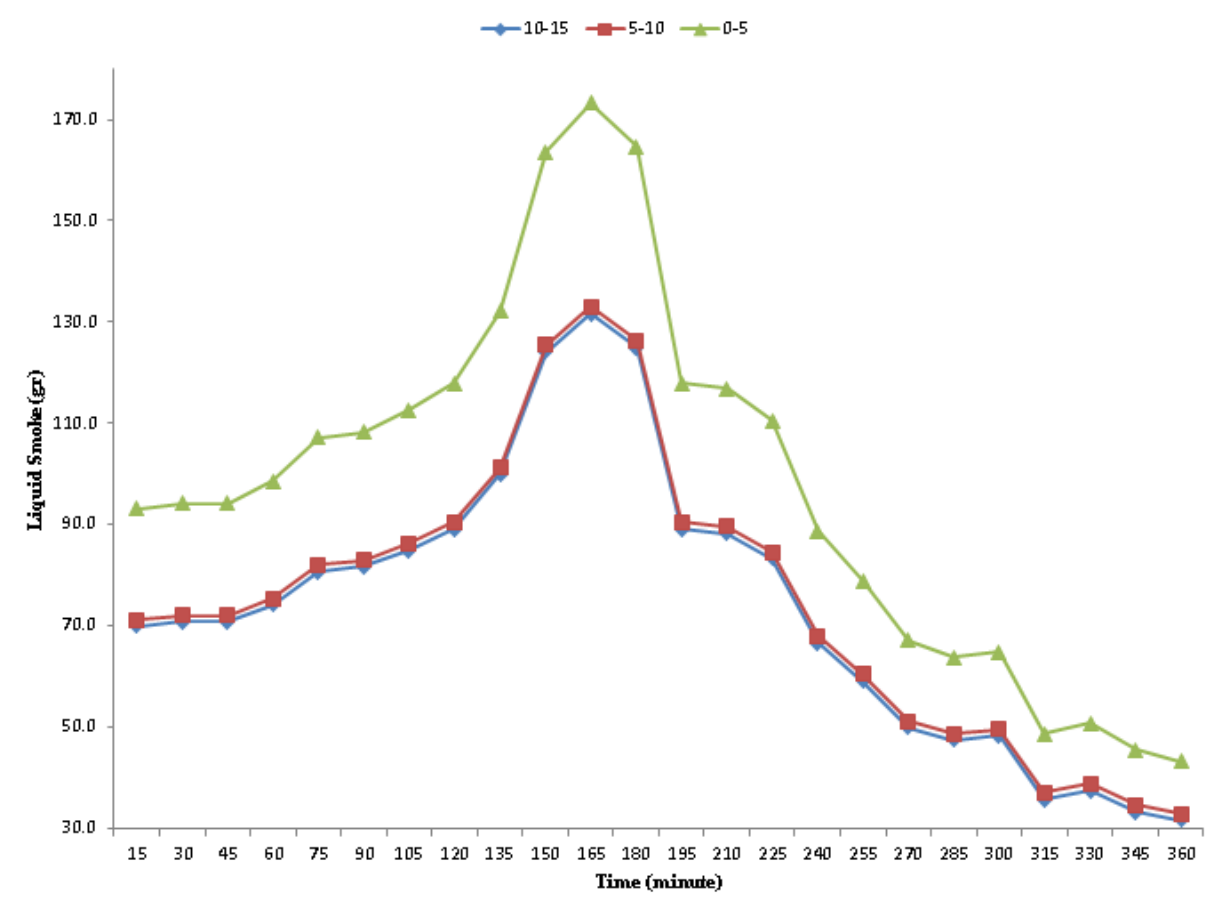

getting less and less. After all, they have decomposed optimally at 165 minutes.

The amount of gas released into the environment can be minimal compared to other studies which in gas escaping as much as $22.9 \%[16]$, and gas escaped as much as $19 \%$ with the same raw material, namely palm kernel shells [17]. While the phenol content in this liquid smoke is higher by an average of $56.18 \%$ compared to research using conventional cooling $13.49 \%[18]$, phenol value also reached $28.3 \%$ with $16 \%$ gas[19]. Other studies on palm kernel shells have also been carried out by using the pyrolysis method using microwave and conventional condensing with $34.91 \%$ phenol and $37.69 \%$ passed gas [20].

\section{CONCLUSION}

Based on these results, it is clear that the smoke condensing system using a controlled refrigeration system can minimize the escape of smoke into the environment which causes air pollution. By using a controlled refrigeration system, it can save energy in the condensing process and can also maximize the production of liquid smoke. The results of liquid smoke using low air temperatures in the smoke condensation process reached an average of $19.8 \%$ with maximum results found at a temperature of $0-5^{\circ} \mathrm{C}$ with a yield of $23.6 \%$ with a phenol content of $56.59 \%$ this also has an impact on the amount gases released or not yet condensed. The gas that comes out reaches an average of $12.6 \%$ with the minimum yield of smoke that comes out occurs at an air temperature of $0-5^{\circ} \mathrm{C}$, namely $8.9 \%$. The amount of this gas can illustrate that the smoke condensation process takes place optimally when compared to the conventional smoke condensing process using water, where the gas can pass into the air up to $37.69 \%$. Thus it can be seen that the less gas that escapes to the environment, the more gas can be condensed automatically so that the productivity of liquid smoke can increase.

\section{REFERENCES}

1. J. Elisabeth and P. S. Ginting. (2003). Utilization of palm oil industry by-products as beef cattle feed ingredients. Oil Palm-Cattle Integr. Syst. Work. p. 110-119.

2. M. A. Shahputra and Z. Zen. (2018). Positive and Negative Impacts of Oil Palm Expansion in Indonesia and the Prospect to Achieve Sustainable Palm Oil. IOP Conf. Ser. Earth Environ. Sci., vol. 122, no. 1, 9-16, DOI: 10.1088/1755-1315/122/1/012008.

3. Fauziati, A. Priatni, and Y. Adiningsih. the effect of various pyrolisis temperature of liquid smoke from palm shells as latex coagulant. J. Ris. Teknol. Ind., p. 139-149.

4. V. Kumar, P. Binod, R. Sindhu, E. Gnansounou, and V. Ahluwalia. (2018). Bioconversion of pentose sugars to value added chemicals and fuels: Recent trends, challenges and possibilities. Bioresour. Technol., vol. 269, 443-451, DOI: 10.1016/j.biortech.2018.08.042.

5. H. M. Morgan et al. (2017). A review of catalytic microwave pyrolysis of lignocellulosic biomass for value-added fuel and chemicals. Bioresour. Technol., vol. 230, 12-121, DOI: 10.1016/j.biortech.2017.01.059.

6. C. L. Yiin, A. T. Quitain, S. Yusup, Y. Uemura, M. Sasaki, and T. Kida, (2018). Sustainable green pretreatment approach to biomass-to-energy conversion using natural hydro-low-transition-temperature mixtures. Bioresour. Technol., vol. 261, 361-369, DOI: 10.1016/j.biortech.2018.04.039.

7. A. sampepana Fauziati. (2015). Characterization of the active component of the refined palm shell liquid smoke. J. Ris. Teknol. Ind., p. 64-72 
8. N. Aprianti, M. Faizal, M. Said, and S. Nasir. (2021). Catalytic gasification of oil palm empty fruit bunch by using Indonesian bentonite as the catalyst. J. Appl. Eng. Sci., 1-10, DOI: 10.5937/jaes0-28781.

9. L. Ni'Mah, M. F. Setiawan, and S. P. Prabowo. Utilization of Waste Palm Kernel Shells and Empty Palm Oil Bunches as Raw Material Production of Liquid Smoke. IOP Conf. Ser. Earth Environ. Sci., vol. 366, no. 1, DOI: 10.1088/1755-1315/366/1/012032.

10. B. Kılınç and Ş. Çaklı. (2012). Growth of Listeria monocytogenes as Affected by Thermal Treatments of Rainbow Trout Fillets Prepared with Liquid Smoke. Turkish J. Fish. Aquat. Sci., vol. 290, 285-290, DOI: 10.4194/1303-2712-v12.

11. J. E. Omoriyekomwan, A. Tahmasebi, and J. Yu. (2016). Production of phenol-rich bio-oil during catalytic fixed-bed and microwave pyrolysis of palm kernel shell. Bioresour. Technol., vol. 207, 188-196, DOI: 10.1016/j.biortech.2016.02.002.

12. M. Faisal and A. Gani. (2018). The effectiveness of liquid smoke produced from palm kernel shells pyrolysis as a natural preservative in fish balls. Int. J. GEOMATE, vol. 15, no. 47, 145-150, DOI: 10.21660/2018.47.06109.

13. Arief Rachmawan, Wijaya, and Andi. (2017). Liquid Smoke Plus As A Latex Clotter. J. agro estate, p.2331

14. I. Kresnawaty, S. M. Putra, A. Budiani, and T. Darmono. (2018). Conversion of Oil Palm Empty Bunches (TKKS) into Biological Charcoal and Liquid Smoke. J. Postharvest Agric. Res., DOI: 10.21082/jpasca. v14n3.2017.171-179.

15. A. Asmawit, H. Hidayati, and N. Supriyatna. (2011). Utilization of Liquid Smoke from Oil Palm Empty Bunches in Raw Rubber Processing. Biopropal Ind., vol. 02 , no. 01, 7-12

16. S. J. Oh, G. G. Choi, and J. S. Kim. (2016). Characteristics of bio-oil from the pyrolysis of palm kernel shell in a newly developed two-stage pyrolyzer. Energy, vol. 113, 108-115, DOI: 10.1016/j.energy.2016.07.044.

17. A. Priatni, Y. Adiningsih, B. Riset, D. Standardisasi, and I. Samarinda. (2018). The effect of various pyrolisis temperature of liquid smoke from palm shells as latex coagulant.J. Ris. Teknol. Ind., p.139-149.

18. G. Chang et al. (2016). The lignin pyrolysis composition and pyrolysis products of palm kernel shell, wheat straw, and pine sawdust. Energy Convers. Manag., vol. 124, no.1, 587-597, DOI: 10.1016/j.enconman.2016.07.038.

19. M. Nayaggy and Z. A. Putra. (2019). Process simulation on fast pyrolysis of palm kernel shell for production of fuel. Indones. J. Sci. Technol., vol. 4, no. 1, 64-73, DOI: 10.17509/ijost.v4i1.15803.
20. Y. An, A. Tahmasebi, X. Zhao, T. Matamba, and J. Yu. (2020). Catalytic reforming of palm kernel shell microwave pyrolysis vapors over iron-loaded activated carbon: Enhanced production of phenol and hydrogen. Bioresour. Technol., vol. 306, no. 1, p. 123111, DOI: 10.1016/j.biortech.2020.123111.

21. K. Endang, G. Mukhtar, Abed Nego, and F. X. A. Sugiyana. (2016). Processing of Plastic Waste with the Pyrolysis Method into Fuel Oil. Dev. Chem. Technol. Process. Indones. Nat. Resour., vol. ISSN 1693, p. 1-7,

22. P. N. Sheth and B. V Babu. (2006). Kinetic Modeling of the Pyrolysis of Biomass. Environ. Eng. vol. 4, no. January, pp. 453-458.

23. A. Kwiecińska, T. Iluk, and M. Kochel. (2016). Utilization of aqueous-tar condensates formed during gasification. J. Ecol. Eng., vol. 17, no. 5, 132-137, DOI: $10.12911 / 22998993 / 65462$.

24. X. Li, J. Ma, and X. Ling. Design and dynamic behaviour investigation of a novel VOC recovery system based on a deep condensation process. Cryogenics (Guildf)., vol. 107, no. 30, p. 103060, DOI: 10.1016/j.cryogenics.2020.103060.

25. M. Sheikholeslami, M. Darzi, and Z. Li, . (2018). Experimental investigation for entropy generation and exergy loss of nano-refrigerant condensation process. Int. J. Heat Mass Transf., vol. 125, 1087-1095, DOI: 10.1016/j.ijheatmasstransfer.2018.04.155.

26. M. Faisal, A. Gani, F. Mulana, H. Desvita, and S. Kamaruzzaman. (2020). Effects Of Pyrolysis Temperature On The Composition Of Liquid Smoke Derivied From Oil Palm Empty Fruit Bunches. Rayasan J., p. 514-520.

27. K. Ridhuan, D. Irawan, and R. Inthifawzi. (2019). Pyrolysis Combustion Process with Biomass Types and Characteristics of the Produced Liquid Smoke. J. Progr. Stud. Tek. Mesin UM Metro, vol. 8, no. 1, p. 69-78.

28. Lisa Ginayati, M. Faisal, and Suhendrayatna. (2015). Utilization of Liquid Smoke from Oil Palm Shell Pyrolysis as Natural Preservative of Tofu. J. Chem. Eng., vol. 4, no. 3, 7-11, DOI: 10.32734/jtk.v4i3.1474.

29. A.R.Trott and T.C.Welch, Refrigeration and Air Conditioning. Butterworth-Heinemann: f Reed Educational and Professional Publishing.

30. A. Mota-Babiloni, J. Navarro-Esbrí, Á. Barragán-Cervera, F. Molés, B. Peris, and G. Verdú.(2015). Commercial refrigeration - An overview of current status. Int. J. Refrig., vol. 57, 186-196, DOI: 10.1016/j.ijrefrig.2015.04.013.

31. B. Withman and B. Johnson. (2006). Refrigeration and Air Conditioning Technology, 6 th. Delmar. 
32. H. Rostamzadeh, T. Gholizadeh, S. Rostamzadeh, S. Vosoughi, and A. A. Farshad. (2021). Role of ejector expander in optimal inherently safety design of cascade NH3/Propane/CO2 vapor compression refrigeration systems. Process Saf. Environ. Prot., vol. 146, 745-762,DOI: 10.1016/j.psep.2020.12.009.

33. T. Łokietek, S. Jaszczak, and P. Nikończuk. (2019). Optimization of control system for modified configuration of a refrigeration unit. Procedia Comput. Sci., vol. 159, 2522-2532, DOI: 10.1016/j. procs.2019.09.427.
34. K. Chen, T. P. Xiao, P. Santhanam, E. Yablonovitch, and S. Fan. (2017). High-performance near-field electroluminescent refrigeration device consisting of a GaAs light emitting diode and a Si photovoltaic cell. J. Appl. Phys., vol. 122, no. 14, DOI: 10.1063/1.5007712.

35. B. Saleh and A. A. Aly. (2015). Flow Control Methods in Refrigeration Systems: A Review Flow Control Methods in Refrigeration Systems : A Review," Int. J. Control. Autom. Syst., p. 12. 